\title{
Analysis on Heat Transmission and Fluid Flow Attributes in Solar Air Accumulator Passage with Diverse Faux Jaggedness Silhouettes on Absorber Panel
}

\author{
Shivasheesh Kaushik, Satyendra Singh
}

\begin{abstract}
There is a necessity to investigate the heat transmission and fluid cascade peculiarities of solar air convectors using varying faux irregular surface and shapes on absorber sheet, so that the solar devices utilize maximum amount of available solar radiated heat energy during day time. These artificial roughness shapes are use for the enhancement of thermal performance. This need arises from the fact that the heat circulation and liquid cascade trait have been investigated by the previous investigators only for the cases that differ considerably from those relevant to solar air brazier having different screen matrix placed in the planes parallel to the flow direction and that the radiant energy being absorbed in depth. In our present research paper we investigating experimentally the behavior of artificial irregularities located over absorber platter of solar air heater vessel of varying shapes like trapezoidal, sin wave, rectangular, alternative elliptical shape pattern etc, with different Reynolds Number range 4000 to 24000, mass flow rate on Nusselt Number and Friction Factor and also find the suitable optimum shape for heat transmission enhancement.

The results indicated the best heat transfer enhancement results for the alternative elliptical shape pattern among other artificial roughness with range of $0.0786 \mathrm{~kg} / \mathrm{s}-$ $0.475 \mathrm{~kg} / \mathrm{s}$ mass flow rate with thermal efficiency near about $78 \%$.
\end{abstract}

Index Terms: Aluminum sheet, artificial roughness, heat transfer characteristics.

\section{INTRODUCTION}

In present scenario government and private thermal power plants, thermal equipment based industries, automobile sectors, digital hardware industries, electrical and electronic sectors focuses on waste heat transfer and waste heat recovery techniques for improving the life and reliability of the products that is only gain by effective heat transfer enhancement through promising equipments, solar air heater for space heating, heat exchanger, radiators, Economizers, cooling systems etc.

To compete in today's global market various studies are conducted to ameliorate the energy efficiency by reducing

Revised Version Manuscript Received on Jun 20, 2019.

Shivasheesh Kaushik, Department of Mechanical Engineering, Shivalik College of Engineering, Uttarakhand Technical University, Dehradun, India.

Satyendra Singh, Department of Mechanical Engineering, B.T.K.I.T Dwarahat, Uttarakhand Technical University, Dehradun, India. the size and cost of heat exchanger. Generally enhancement of heat transfer is based on following factors which involves geometrical parameters of equipments like area, length, diameter etc, physical and chemical characteristics of materials and fluids such a viscosity, density, specific heat, thermal conductivity, flow rate of fluids, temperature difference etc, counter flow and parallel flow of fluid, heat transfer coefficient, perforation, pressure drop, insulation, fouling factor etc.

These factors play an important role in heat transmission while designing the heat circulation or transmission equipments namely Double-pipe exchanger for cooling and heating, fins, heat exchanger with and without inserts and baffles, shell and tube exchangers for all applications, tube and fin heat exchangers for all applications, Plate and heat exchangers for heating and cooling, heat exchanger with micro channels, Plate-fin heat exchangers, Spiral heat exchangers with and without inserts, helical coil heat exchangers with or without baffles, Cooling systems including coolers and condensers, radiators etc, agitated vessels, economizers, fired heaters.

There are two different ways which influences the efficiency and effectiveness of the thermal equipments like heat exchangers, radiators, condensers, economizers etc, and are very famous among thermal equipment based industries. The wide use of heat transfer equipment now a day's in diverse areas for resolving heat transfer related problems such as improvement of product efficiency, waste heat recovery and effective utilization heat loss for thermal equipments like heat exchanger and economizers etc, which are use in thermal power station, enhancement of soldering life and reliability of LEDs, laptops and circuit boards in electrical and electronics sectors, manufacture a promising and reliable engine cooling system in automobile sectors.

Such areas of applications emphasis and attracts present researchers and provide them a platform for their innovative creations for enhancing heat transfer rate, working efficiency, effectiveness, reliability, waste heat recovery of different types of thermal equipments like heat exchangers, radiators, condensers, economizers etc in various sectors.

Such type of enhancements are only possible when these two methods will execute positively

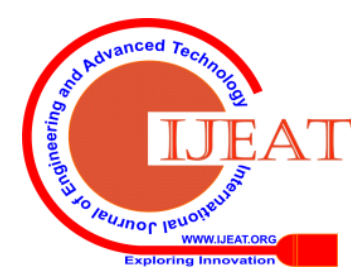


with optimized operating parameters,

first method based on improvement of structural design efficiency of equipment and second is based on improvement of fluid properties. Structural design efficiency is achieved by accomplishing five major phases that is selection of geometrical shape and size, selection of radial and longitudinal spacing between tubes, plates, baffles, inserts and micro channels etc, selection of geometrical design of artificial roughness like baffles, inserts/fins, ribbed inserts/fins and micro channels etc, selection of combination of geometrical design as per required application such as single tubes, single plate, multiple plate, multiple tubes, number of tubes with baffles, number of tubes with inserts or fins, number of tubes with perforated or ribbed inserts/fins, number of tubes with micro channels and at last selection of material for tubes, baffles, inserts and micro channels. Optimum selection of all phases as per required operating condition of equipments and applications enhance the structural design efficiency and reliability of thermal equipments.

Fluid properties are improved by treatment of fluid at micro level and this is achieved by accomplishing five major phases that is selection of nano particle material and base fluid as per required physical and chemical properties, preparation of nano particles in required size as per operating condition of equipments and applications, selection of optimum and accurate stabilizer with perfect volume percentage so that life period and stability of nanofluids will enhance, preparation of nanofluids with optimum volume concentration as per required operating condition of equipments and applications through ultra sonication technique, selection of nanofluids or nano emulsion for the equipment as per required operating condition of equipments and applications, selection of direction of fluid flow that is counter flow or parallel flow. Optimum selection of all phases as per required operating condition of equipments and applications enhance the fluid properties. Execution of both methods simultaneously improves the efficiency area of the system where the equipment is installed.

In 2016 Alok Kumar investigate experimentally about flow peculiarities of single tube heat exchanger having different inserts like SHCD inserts and CPRI inserts with a specific test section of 2.5 long pipe and 1.4 long. The result depicts maximum at $\mathrm{DR}=0.6 \& \mathrm{PI}=1$ And $\mathrm{TPF}$ is maximum at $\mathrm{DR}=0.8 \& \mathrm{PR}=1$ for $\mathrm{SHCDI}$ and $\mathrm{f}$ and $\mathrm{Nu}$ is maximum at $\mathrm{DR}=0.6 \& \mathrm{PI}=8 \%$ But $\mathrm{TPF}$ is maximum at $\mathrm{DR}=0.8 \& \mathrm{PI}=$ $24 \%$ for CPRI [1]. In 2016 Vijay Pal Singh investigate experimentally about heat transmission and flow peculiarities of air in single THE having MTT and SR Inserts with a specific test section of 2.5 long inlet section of pipe and 1.4 long.[3]. In 2011 Smith Eiamsa-ard investigate experimentally about heat transmission and flow peculiarities of air in CHE having DSDWT Insert with Alternate-axes. The result depicts that $\mathrm{f}$-wing perform better than B-wing and dimensional less number is increased by $165 \%$ \& f by 14.8 times of plain tube. [4]. In Year 2018 R.M. Sarviya, Veeresh Fuskele investigate experimentally about heat transmission and pressure drop of water in $\mathrm{CHE}$ having
CRCTT inserts with a specific test section which include copper tube dia $=20 \mathrm{~mm}, \mathrm{t}=1 \mathrm{~mm}$ and $\mathrm{L}=1000 \mathrm{~mm}$. The experimental setup has a developing section of $2.5 \mathrm{~m}$, test section of $1 \mathrm{~m}$ and then calming section of $1 \mathrm{~m}$ and results depicts that the maximum dimensionless number are obtained at twisted ratio of 3 . But maximum TPF was found at twisted ratio of 5 [10]. In Year 2017 and 2018 N.T. Ravi Kumar et. al. investigate experimentally about heat transmission and effectiveness of $\mathrm{Fe} 3 \mathrm{O} 4 /$ water nano fluid in DPHE with a specific test section and results depicts that the all values are taken at $0.6 \% \mathrm{VC}$ of nano particles better performance in heat transmission [11,12]. In Year 2017 Abhishek Gautam et. al. investigated experimentally about heat transmission and flow peculiarities in a CHE tube of air in Perforated triple WVG with a specific test section which include a special setup is mainly compromised of test section arrangements for heating purpose and air circulating system. The results depicts that $\mathrm{Nu}$ and $\mathrm{f}$ are max at $\beta=0 \%$, twist ratio $=2$, whereas TPF is $\max$ at $\beta=30 \%$ and twist ratio $=2$ [13]. There are various other investigators which contributed their research and performed work on different experimental setups in same area and field with diverse shape inserts like DCTT, V- nozzle turbulator, inclined vortex rings, circular-ring turbulators, MSPTT Inserts, STT Inserts and shows a promising enhancement in heat transmission and dimensionless numbers as compared smooth tube and duct $[2,5,6,7,8,9,14]$

\section{THE OBJECTIVE OF THE PRESENT RESEARCH}

The objective of present research study is based on the following areas, which are as follows:

1- Present research paper investigate experimentally the culmination of counterfeit jaggedness located over absorber salver of solar astir brazier channel of varying shapes like trapezoidal, rectangular, plain/smooth surface, alternative elliptical pattern etc, with different mass flow rate on Nusselt Number and Friction Factor.

2- Determining the suitable optimum shape for heat transfer enhancement.

3- Evaluating the optimum thermal efficiency for optimum artificial roughness shape at optimum mass flow rate.

\section{MATERIAL AND METHODOLOGY}

The rapid development of numerical techniques, experimental set up and CAD software which is a powerful time saving tool, improves overall efficiency, resources savings and to assist the engineer in creation, modification, analysis and display of the design. Graphic and solid modeling software are used to generate a design and represent it on screen. In analysis software it make use of stored data relating to design and applies it to various analytical studies for example ANSYS, it offers a design optimization module for effective synthesizing of design into optimized product. CFD (ANSYS) software empowers engineers to solve highly sophisticated engineering problems. 
The present investigation is based on experimental set up and numerical technique this was influenced by the following theoretical research as shown in table number 3.1 .

Table Number 3.1: Various Results of Previous Investigation done by Researchers

\begin{tabular}{|c|c|c|c|c|c|c|}
\hline $\begin{array}{l}\text { S.No } \\
.\end{array}$ & $\begin{array}{l}\text { AUTHOR } \\
\text { NAME } \\
\end{array}$ & METHODOLOGY & PROFILE & $\begin{array}{c}\text { RESEARCH } \\
\text { AREA } \\
\end{array}$ & RESULT DEPICTED & REFERENCE \\
\hline 1 & $\begin{array}{l}\text { V.S.Hans } \\
\text { et.al. }\end{array}$ & Mathematical Model & $\begin{array}{l}\text { Multiple } \\
\text { V-Ribs }\end{array}$ & $\begin{array}{l}\text { Heat transfer } \\
\text { and Friction } \\
\text { Factor }\end{array}$ & $\begin{array}{l}6 \text { to } 5 \text { time more heat } \\
\text { transfer achieved than SAP }\end{array}$ & 14 \\
\hline 2 & $\begin{array}{l}\text { B. Bhushan } \\
\text { et.al. }\end{array}$ & Mathematical Model & PAP & $\begin{array}{l}\text { Thermal and } \\
\text { Thermo } \\
\text { hydraulic } \\
\text { performance }\end{array}$ & $\begin{array}{l}\text { Optimum value of Thermal } \\
\text { efficiency criteria for } \\
\text { Protruded absorber plate is } \\
\text { independent of rise of } \\
\text { temperature parameters } \\
\text { and there was a increment } \\
\text { of } 2.3 \text { time than smooth } \\
\text { absorber plate on the other } \\
\text { hand Optimum value of } \\
\text { Effective efficiency criteria } \\
\text { is function of rise of } \\
\text { temperature parameters } \\
\text { and there was a increment } \\
\text { of } 2.2 \text { time than smooth } \\
\text { absorber plate }\end{array}$ & 15 \\
\hline 3 & $\begin{array}{l}\text { P.Dhiman } \\
\text { et.al. }\end{array}$ & Analytical model & PBSAH & $\begin{array}{l}\text { Thermal } \\
\text { Performance }\end{array}$ & $\begin{array}{l}10 \% \text { to } 20 \% \text { enhancement } \\
\text { of thermal efficiency was } \\
\text { predicted for Parallel flow } \\
\text { PBSAH than conventional } \\
\text { non porous DFSAH }\end{array}$ & 16 \\
\hline 4 & $\begin{array}{l}\text { A.A. } \\
\text { El-Sebaii } \\
\text { et.al. }\end{array}$ & $\begin{array}{l}\text { Experimental set up } \\
\text { and Theoretical } \\
\text { Model }\end{array}$ & $\begin{array}{l}\text { Double pass } \\
\text { VCPSAH } \\
\text { and double } \\
\text { pass FPSAH }\end{array}$ & $\begin{array}{l}\text { Thermal } \\
\text { Performance }\end{array}$ & $\begin{array}{l}\text { Double pass VCPSAH is } \\
9.3-11.9 \% \text { more efficient } \\
\text { compared to the double } \\
\text { pass FPSAH }\end{array}$ & 17 \\
\hline 5 & $\begin{array}{l}\text { G.G. Mohit } \\
\text { Kumar et.al. }\end{array}$ & $\begin{array}{l}\text { Experimental set up } \\
\text { and Theoretical } \\
\text { Model }\end{array}$ & $\begin{array}{l}\text { DFSAH with } \\
\text { Multiple C } \\
\text { Shape } \\
\text { Roughness }\end{array}$ & $\begin{array}{l}\text { The Thermal } \\
\text { and hydraulic } \\
\text { performance }\end{array}$ & $\begin{array}{l}\text { Multiple C-shaped ribs in } \\
\text { DFSAH provides better } \\
\text { heat transfer results than } \\
\text { other arrangements }\end{array}$ & 18 \\
\hline 6 & $\begin{array}{l}\text { S.S. } \\
\text { Krishnanant } \\
\text { h et.al. }\end{array}$ & $\begin{array}{l}\text { Experimental } \\
\text { Analysis }\end{array}$ & $\begin{array}{l}\text { SAH with } \\
\text { Thermal } \\
\text { Reservoir } \\
\text { using } \\
\text { Paraffin } \\
\text { Wax }\end{array}$ & $\begin{array}{l}\text { Thermal } \\
\text { Efficiency }\end{array}$ & $\begin{array}{l}\text { The efficiency of the SAH } \\
\text { with thermal reservoir } \\
\text { using paraffin wax was } \\
\text { higher than normal heater } \\
\text { without thermal reservoir } \\
\text { system }\end{array}$ & 19 \\
\hline 7 & $\begin{array}{l}\text { K. Kumar } \\
\text { et.al. }\end{array}$ & $\begin{array}{l}\text { Experimental set up } \\
\text { and Theoretical } \\
\text { Model }\end{array}$ & $\begin{array}{l}\text { S Shape } \\
\text { Wire Rib }\end{array}$ & $\begin{array}{l}\text { Thermal } \\
\text { Performance }\end{array}$ & $\begin{array}{l}\mathrm{S} \text { shaped rib artificial } \\
\text { roughness absorber plate in } \\
\text { SAH provides better heat } \\
\text { transfer results than SAP }\end{array}$ & 20 \\
\hline 8 & $\begin{array}{l}\text { F. Menasria } \\
\text { et.al. }\end{array}$ & Experimental set up & $\begin{array}{l}\text { Rectangular } \\
\text { Baffles }\end{array}$ & $\begin{array}{l}\text { Thermal } \\
\text { Performance }\end{array}$ & $\begin{array}{l}\text { Baffles in Rectangular } \\
\text { cross section of SAH } \\
\text { provides better heat transfer } \\
\text { results than SAP }\end{array}$ & 21 \\
\hline
\end{tabular}


Analysis on Heat Transmission and Fluid Flow Attributes in Solar Air Accumulator Passage with Diverse Faux Jaggedness Silhouettes on Absorber Panel

\begin{tabular}{|c|c|c|c|c|c|c|}
\hline 9 & $\begin{array}{l}\text { L. Varshney } \\
\text { et.al. }\end{array}$ & CFD Analysis & $\begin{array}{l}\text { Multiple } \\
\text { SPTT } \\
\text { Inserts }\end{array}$ & $\begin{array}{l}\text { Heat Transfer } \\
\text { Enhancement }\end{array}$ & $\begin{array}{l}\text { Results shows and } \\
\text { increment in heat } \\
\text { transmission than Plane } \\
\text { tube and Maximum values } \\
\text { obtained at } 2.5 \text { twist ratio } \\
\text { and } 0.250 \text { width ratio of } \\
\text { perforation }\end{array}$ & 22 \\
\hline 10 & $\begin{array}{l}\text { S. Eiamsaard } \\
\text { et.al. }\end{array}$ & Experimental set up & $\begin{array}{l}\text { Sectioned T } \\
\text { R Roughness }\end{array}$ & $\begin{array}{l}\text { Thermal } \\
\text { peculiarities }\end{array}$ & $\begin{array}{l}\text { Sectioned } \mathrm{T} R \text { Roughness } \\
\text { Profile shows better results } \\
\text { of Heat transmission } \\
\text { peculiarities, } \mathrm{f} \text { and } \mathrm{TPF} \\
\text { than Plain profile }\end{array}$ & 23 \\
\hline 11 & $\begin{array}{l}\text { A. Gautam } \\
\text { et.al. }\end{array}$ & $\begin{array}{l}\text { Experimental set up } \\
\text { and Theoretical } \\
\text { Model }\end{array}$ & $\begin{array}{l}\text { Perforated } \\
\text { TWVG }\end{array}$ & $\begin{array}{l}\text { Heat } \\
\text { Transmission } \\
\text { and Flow } \\
\text { Peculiarities } \\
\text { in a HET }\end{array}$ & $\begin{array}{l}\text { Nu and } f \text { are max at } \beta=0 \% \text {, } \\
\text { twist ratio=2, whereas TPF } \\
\text { is } \max \text { at } \beta=30 \% \text { and twist } \\
\text { ratio }=2\end{array}$ & 24 \\
\hline 12 & $\begin{array}{l}\text { N.T. Ravi } \\
\text { Kumar et.al. }\end{array}$ & Experimental set up & $\begin{array}{l}\text { Twisted tape } \\
\text { inserts }\end{array}$ & $\begin{array}{l}\text { Analysis of } \\
\text { Heat } \\
\text { transmission } \\
\text { and flow } \\
\text { peculiarities }\end{array}$ & $\begin{array}{l}\text { All values are taken at } \\
0.06 \% \text { VC of nano particles } \\
\text { and shows promising } \\
\text { results than normal plane } \\
\text { fluid }\end{array}$ & 25 \\
\hline 13 & $\begin{array}{l}\text { A.Kumar } \\
\text { et.al. }\end{array}$ & $\begin{array}{l}\text { Experimental set up } \\
\text { and Theoretical } \\
\text { Model }\end{array}$ & $\begin{array}{l}\text { Solid HCD } \\
\text { inserts and } \\
\text { CC tube with } \\
\text { CPR inserts }\end{array}$ & $\begin{array}{l}\text { Thermal } \\
\text { Performance }\end{array}$ & $\begin{array}{l}\text { For Solid HCD inserts } 1.4 \\
\text { times improvement in TPF } \\
\text { for PR }=1 \text { and DR }=0.8 \\
\text { when compared to STHE } \\
\text { and for CC tube with CPR } \\
\text { inserts } 1.47 \text { times } \\
\text { improvement occurred in } \\
\text { TPF for PI = 24\% and DR = } \\
0.8 \text { as compared to STHE }\end{array}$ & 26,28 \\
\hline 14 & $\begin{array}{l}\text { S. Şevika } \\
\text { et.al. }\end{array}$ & Experimental set up & $\begin{array}{l}\text { Aluminum } \\
\text { FFA Duct }\end{array}$ & $\begin{array}{l}\text { Thermal } \\
\text { Performance }\end{array}$ & $\begin{array}{l}\text { Result depicted Aluminum } \\
\text { FFA duct have average } \\
81.3 \% \text { efficiency and } \\
15.9-41.2 \% \text { average } \\
\text { efficiency was evaluated for } \\
\text { the Re range } 1447-28355 \\
\text { as compared to normal } \\
\text { SAC }\end{array}$ & 27 \\
\hline
\end{tabular}

\section{DESIGN OF RECTANGULAR DUCT}

In order to obtain reliable and accurate experimental data from radiate heated wire screen matrix packed in the solar air heater duct to the flowing air, the following important considerations have been made for the design of various components of the experimental set-up.

\section{A. Test Sections}

The dimensions of the ducts have been decided on the basis of recommendations by Beckman et al. Accordingly, the length of the solar collector test duct should range from $1.00 \mathrm{~m}$ to $1.25 \mathrm{~m}$. a higher length in the recommended range result in higher exposed area of the collector and hence, higher collection of energy.

This will lead to lesser experimental error (same experimental error added to higher amount of energy gain will add lesser error percentage if the same amount is added to lesser energy gain.

\section{B. Entry and Exit Section}

As per ASHRAE standard recommendations, the length of the flow straightened downstream of the test section should be taken at minimum value of $5 \sqrt{ } \mathrm{A}_{\mathrm{f}}$, whereas, the length of mixing section be minimum of $2.5 \sqrt{ } \mathrm{A}_{\mathrm{f}}$, having the same cross sectional area, $\mathrm{A}_{\mathrm{f}}$ as that of the test section.

Width of rectangular section, $\mathrm{W}=320 \mathrm{~mm}$

Height of rectangular section, $\mathrm{H}=25 \mathrm{~mm}$

As per ASHRAE standard, entry section $=5 \sqrt{ }(\mathrm{WH})=450 \mathrm{~mm}$ As per ASHRAE standard, exit section $=2.5 \sqrt{ }(\mathrm{WH})=225$ $\mathrm{mm}$

Test section $=1000 \mathrm{~mm}$ 


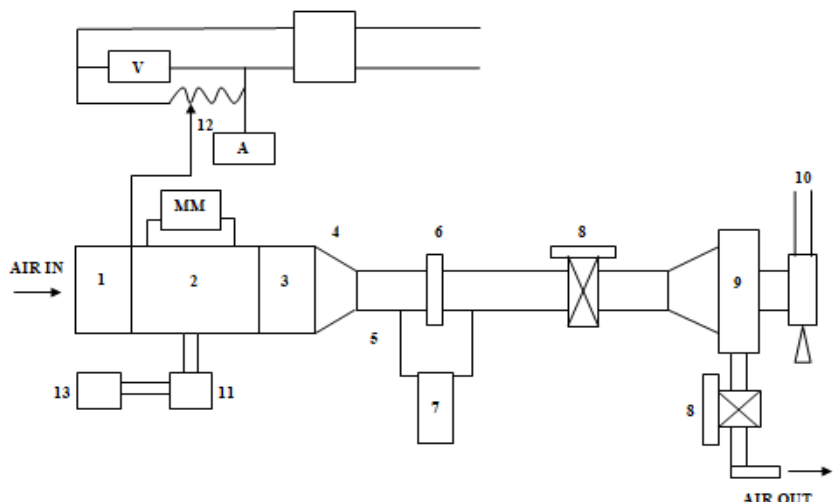

Fig 3.1 Schematic Diagram of Experimental Setup Side View

\section{METHODOLOGY}

The following steps are involved in the present work:

- Design of experimental setup

- Fabrication of experimental setup

- Selection of different roughness geometry

- Determine the varying Range of operating parameters

- Experimental investigation under simulated condition

\section{DESCRIPTION OF EXPERIMENTAL SETUP}

The experimental set up employed in the present investigation is shown photographically (two different views in Figs. 3.5 and 3.6) and schematically in Fig.3.1. It essentially consists of following main components, fabricated in accordance with the design considerations.

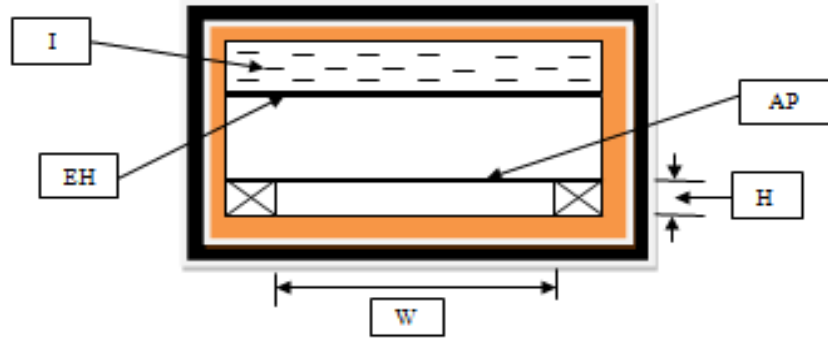

Fig 3.2 Schematic Diagram of Experimental Setup Front View

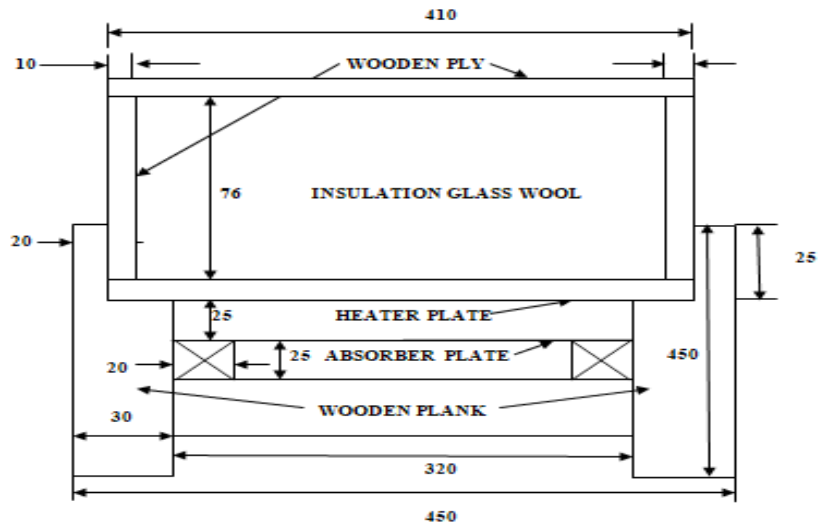

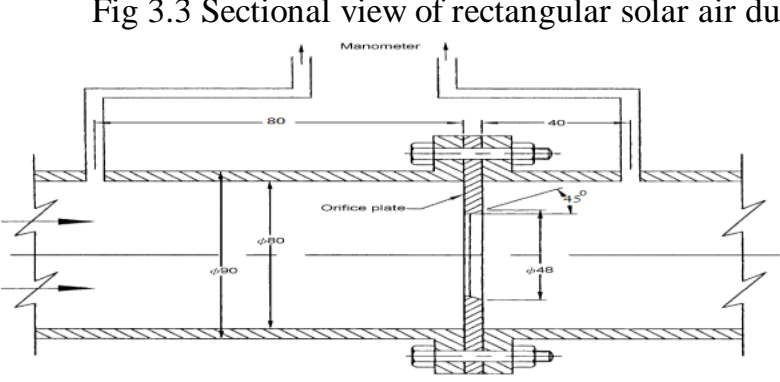

(a)

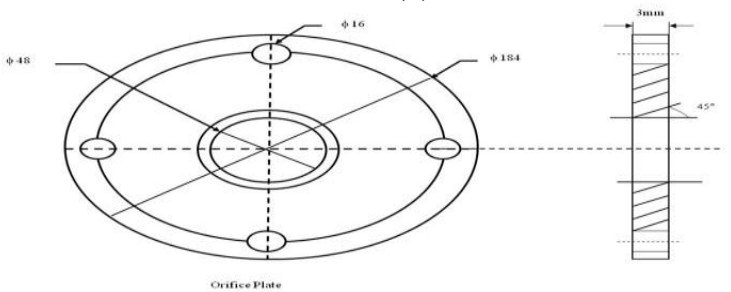

(b)

Fig 3.3 (a) Recommendation Location of Pressure taps for use with concentric, thin plate, square edge orifices (b) Design and Fabricated Orifice meter

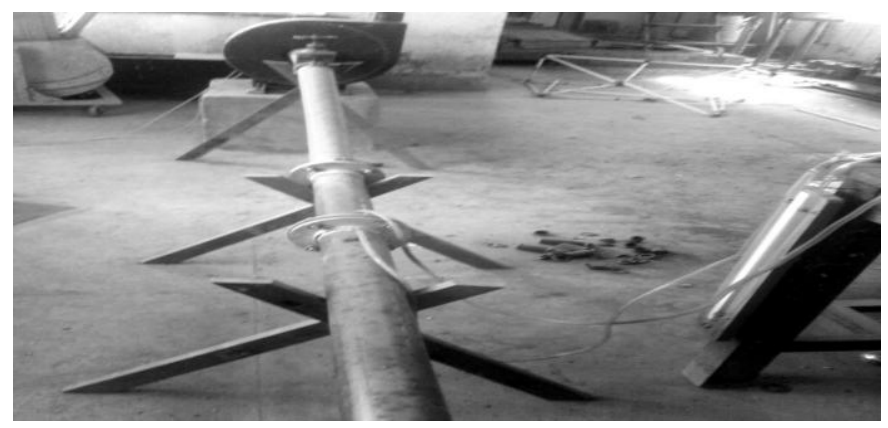

Fig. 3.5 Photographic view of experimental setup (blower side)

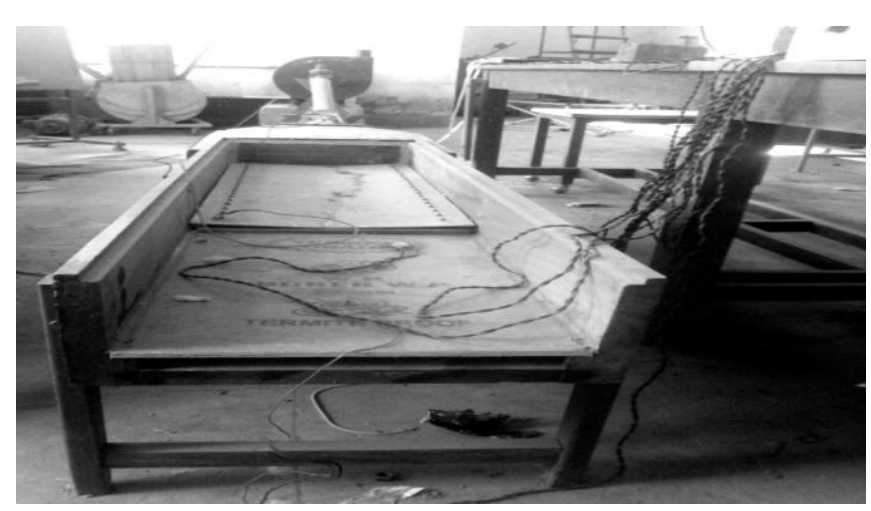

Fig. 3.6 Photographic view of experimental setup (duct side)

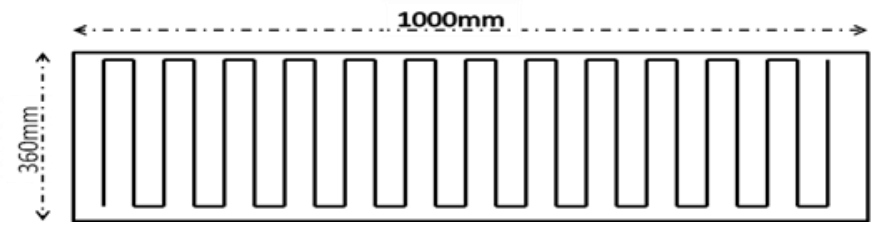

The strip heater is made up of asbestos sheet and nichrome

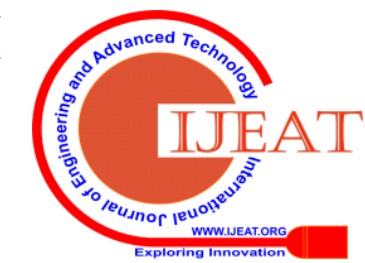


wire and screws. The strip heater is $1000 \mathrm{~mm}$ in length and $320 \mathrm{~mm}$ in width. Over $4 \mathrm{~mm}$ thick asbestos sheet nichrome wires are fixed. The strip heater gave heat to the aluminum plate. Disrobe warmer is propped $25 \mathrm{~mm}$ above the aluminum salver on the wooden baton to supply heat to the aluminum plate.

\section{EXPERIMENTAL PROCEDURE}

After fabrication of experimental set which was based on ASHRAE standard, the measurement devices like $U$ tube manometer, orifice, thermocouple, data logger, digital temperature indicator etc were assembled for determining the mass flow rate and temperature through the absorber duct. Electrical connections and devices were installed properly at heater and blower area namely variac and switches with a proper constant set point voltage.

Before starting the experimentation all joints are fixed through $\mathrm{m}$ seal, for avoiding the leakage. Variac fixed at constant set point voltage due to which a fix voltage is received to heater and blower section of experimental set up, this action allows heater and blower to developed constant heat flux and constant mass flow rate which was further delivered to test section of experimental set up after achieving steady state condition.

First step of experimentation was to develop a steady state condition and that was achieved after 2-2.5 hours when heater and blower switch on and variac supply a constant set point voltage. After steady state condition developed, different reading of temperature was noted from several thermocouples which was located at different position on absorber test section duct of experimental setup through changing the selector switch position in temperature indicator device and further reading was parallels noted through data logger device which was connected to experimental setup and laptop.

The above procedure followed again and again for spurious jaggedness patterns on absorber platter like trapezoidal, rectangular, plane and smooth, alternative elliptical pattern etc, with different mass flow rate and heat flux for evaluating diverse Nusselt Number and Friction Factor

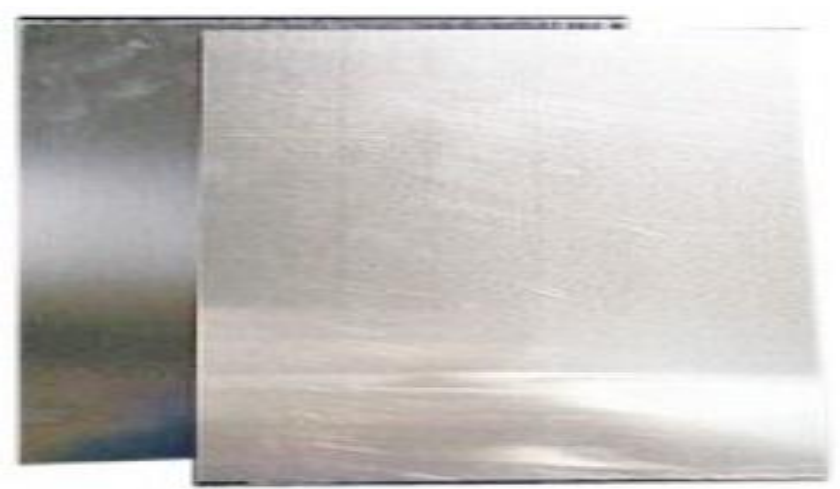

(a) Plane and smooth Roughness

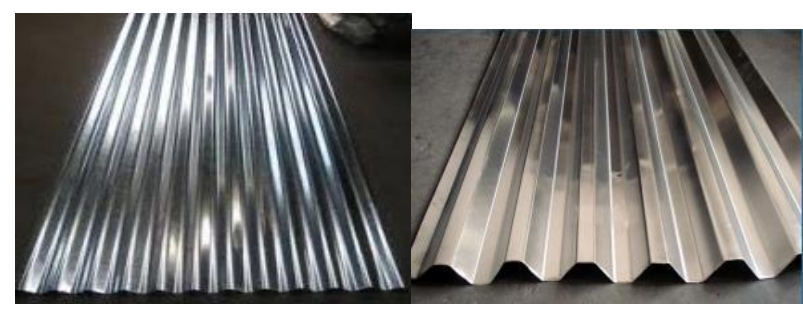

(b) Sine wave Roughness

(c) Trapezoidal Roughness

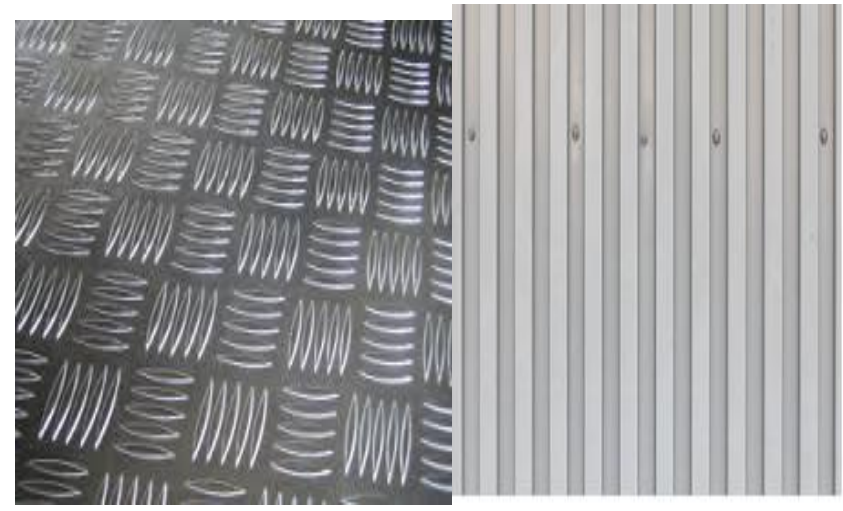

(d) Rectangular Roughness Roughness

(e) Alternative Elliptical

Fig. 4.1 Photographic view of different shape of artificial roughness on aluminum sheet

\section{GOVERNING EQUATIONS}

\section{A. Result Validation Test For The Smooth Collector}

The Nusselt number and friction factor determined from the experimental data for varying spurious irregularities have been compared with the values obtained from Blasius equation and Dittus -Boelter equation for Nusselt number and friction factor respectively.

- Dittus -Boelter Equation :

(5.1)

$$
\mathrm{Nu}_{\mathrm{s}}=0.023 \operatorname{Re}^{0.8} \operatorname{Pr}^{0.4}
$$

- Modified Blasius Equation :

$$
\mathrm{f}_{\mathrm{s}}=0.085 \mathrm{Re}^{-0.25}
$$

- Karman- Nikuradse Equation:

$$
\mathrm{f}_{\mathrm{s}}=0.046 \operatorname{Re}^{-0.2}
$$

\section{B. Procedure For Data Reduction}

The raw data has been used to determine the desired parameter as discussed below [13]:

\section{a. Porosity of matrix, $\mathrm{P}$}

Calculation of Porosity of the absorber duct has been based on the number of layers of wire screen and its geometric specifications.

$$
\mathrm{P}=\frac{\mathrm{V}_{\mathrm{L}}-\mathrm{V}_{\mathrm{S}}}{\mathrm{V}_{\mathrm{S}}}=\frac{\mathrm{P}_{\mathrm{I}}^{2} \mathrm{D}-\left[\pi_{\mathrm{f}} / 2\left(\mathrm{~d}_{\mathrm{W}}\right)^{2} \mathrm{p}_{\mathrm{t}}\right] \mathrm{N}}{\mathrm{P}_{\mathrm{L}}^{2} \mathrm{D}}
$$


b. Mass flow rate, $\mathrm{m}$

Calculation of mass flow rate, using the following equation: $m=C_{d} A_{2}\left[\frac{2 \rho \Delta P_{0}}{1-\beta^{4}}\right]^{0.5}$

Where,

$$
\begin{aligned}
& C_{d}=\text { coefficient of discharge } \\
& A_{2}=\text { area of orifice } \\
& \beta=\text { ratio of orifice to pipe diameter } \\
& \rho=\text { the density of air }
\end{aligned}
$$

Its value is obtained after calibration of orifice plate against a standard pitot tube is found to be 0.62 .

$$
\begin{gathered}
\text { Area of orifice, } A_{2} \\
A_{2}=\frac{\pi}{4}\left(D_{2}\right)^{2}
\end{gathered}
$$

$$
\text { c. Reynolds number, } \operatorname{Re}_{\mathrm{p}}
$$

Calculation of Reynolds number for packed absorber duct has been based on the following equation:

$$
R e_{p}=\frac{4 r_{h} G_{p}}{\mu}
$$

Where the hydraulic radius, $\mathrm{r}_{\mathrm{h}}$ for packed absorber ducts is the ratio of void volume to wetted surface area and is calculated as:

$$
r_{h}=\frac{P d_{w}}{4(1-P)}
$$

and mass velocity, Go is calculated as:

$$
\mathrm{G}_{0}=\frac{m}{A_{f} P}
$$

d. Average matrix temperature $\bar{t}_{m e}$

Weight average temperature of wire mesh has been evaluated based on the assumption that thermocouple located at a particular position indicates average temperature of the volume of the matrix covered by this thermocouple. The weight average temperature has been calculated as follows:

$$
\begin{aligned}
& \bar{t}_{m e}=\frac{1}{1000}\left[1 0 0 \left(\mathrm{t}_{1}+\mathrm{t}_{6}+\mathrm{t}_{11}+\right.\right. \\
& \left.\mathrm{t}_{16}+\mathrm{t}_{21}\right) / 5+300\left(\mathrm{t}_{2}+\mathrm{t}_{7}+\mathrm{t}_{12}+\right. \\
& \left.\mathrm{t}_{17}+\mathrm{t}_{22}\right) / 5+500\left(\mathrm{t}_{9}+\mathrm{t}_{9}+\mathrm{t}_{13}+\right. \\
& \left.\mathrm{t}_{18}+\mathrm{t}_{23}\right) / 5+300\left(\mathrm{t}_{4}+\mathrm{t}_{9}+\right. \\
& \left.\mathrm{t}_{19}+\mathrm{t}_{24}\right) / 5+100\left(\mathrm{t}_{5}+\mathrm{t}_{10}+\right. \\
& \left.\left.\mathrm{t}_{15}+\mathrm{t}_{25}\right) / 5\right]
\end{aligned}
$$

e. Mean bulk air temperature $\left(\bar{t}_{f}\right)$ :

$$
\bar{t}_{f}=\frac{t_{p}-t_{i}}{2}
$$

\section{f. Heat gain, $Q_{u}$}

$Q_{u}$ is a product of $\mathrm{m}, \mathrm{C}_{\mathrm{p}}$ and $\left(\mathrm{t}_{0}-\mathrm{t}_{\mathrm{i}}\right)$

$$
Q_{u}=m C_{p}\left(t_{0}-t_{i}\right)
$$

g. Average heat transfer coefficient
Determination of average heat transfer coefficient, $h_{c}$ between wire screen matrix and air was based on following equation:

$$
H_{c}=\frac{Q_{u}}{A\left(f_{u x}-F_{f f}\right)}
$$

(6.9) Where, $\bar{t}_{m e}$ is the average mess temperature based on the average of the temperature measurement made along the length and depth of the packed absorber duct and, $\bar{t}_{f}$ is the average air temperature,

The heat transfer area, A has been determine on the basis of the following relation

$$
A=\frac{4 A_{f} L[(1-P)}{d_{W}}
$$

h. Station number

Stanton number defines by the following equation:

$$
S_{t}=\frac{\hbar_{c}}{\left(G_{0} \times c_{p}\right)}
$$

i. Colburn J-Factor

The J-factor is given by the following equation:

$$
\tilde{h}_{\mathrm{h}}=S t \cdot \operatorname{Pr}^{2} \mathrm{~d}^{\mathrm{a}}
$$

j. Friction Factor, Fp

Using the pressure drop data, the Friction factor has been calculated using the following equation:

$$
f_{p}=\frac{r_{h \Delta P} f_{L}}{\rho u^{2} / 2 g_{c}}
$$

Where, $\mathrm{u}$, the air velocity in the packed absorber duct is calculated as follows:

$$
u=\frac{G_{0}}{\rho}
$$

\section{k. Thermal efficiency, $\eta$}

The thermal efficiency has been calculated using the following equation both for smooth as well as packed absorber duct

$$
\eta=\frac{G_{0} C_{p} \Delta t}{I}
$$

\section{RESULT AND DISCUSSION}

A proper and intense theoretical investigation has been done to made an effective experimental set up in the present paper to evaluate the values and culmination of Nusselt number and Friction factor on heat transmission intensification attributes of spuriously crooked channel in solar astir brazier using of different shapes of geometry with varying mass flow rate. It has been sincerely observed that after experimentation there was a considerable improvement in heat transmission as compared with plain aluminum absorber plate. This will interesting to see further work that how correlations can be developed 
for heat transmission with different dimensional less numbers and parameters for solar stirring convector passages having counterfeit unevenness of varying patterns for different investigators. These correlations can be used to evaluate the system efficiency, effectiveness and hydraulic or thermo hydraulic performance of spurious irregularities solar stirring convector passages.

Above information mentioned in this research paper will be useful for the starters or fresher's in this relevant area of research to determine and optimize the new factors which effects the experimental process with diverse fluids and innovative or creative geometries for achieving the maximum enhancement of heat transfer.

After comparing of experimental values of Nusselt number and friction factor with numerical data reduction values, which is achieved form different shape of artificial roughness, we find that random parabolic shape shows an optimum result as compared to other selected shapes, which is responsible for considerable enhancement of heat transfer with varying range of mass flow rate and Reynolds number of $0.0787 \mathrm{~kg} / \mathrm{s}-0.472 \mathrm{~kg} / \mathrm{s}$ and 4000 to 24000 .

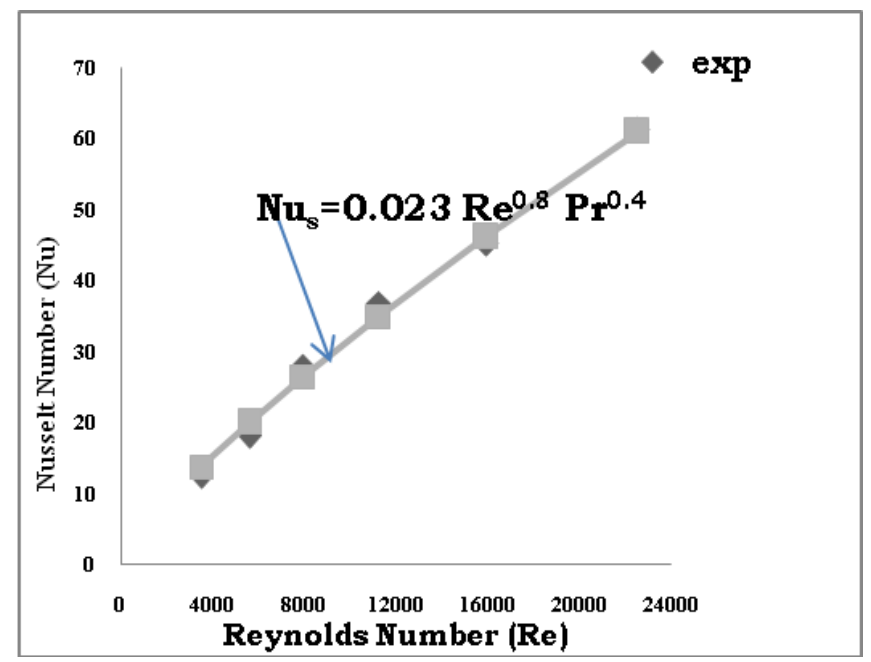

Fig 5.1: Graphical validation of experimental and numerical data reduction correlation values of Nusselt number for Smooth Aluminum Plate.

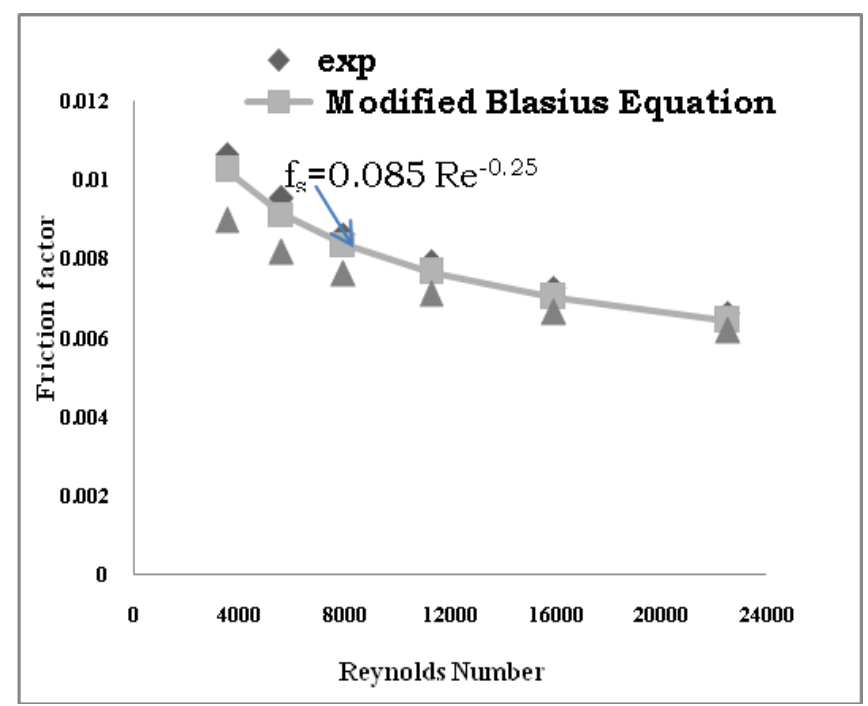

Fig 5.2: Graphical validation of experimental and numerical data reduction correlation values of Friction number for Smooth Aluminum Plate.

The optimum results of random parabolic shape on absorber plate for Nusselt number and friction factor are presented through graphical representation as shown in figure 5.1 and 5.2.

The predicted values of Nusselt number and friction factor was extracted by following the data reduction process and mainly 6.13 and 5.1, 5.2, 5.3 equations plays an important role and also responsible for the numerical and experimental analysis. The experimental values of Nusselt number and friction factor was obtained from testing set as shown in figure 3.5 and 3.6.

From figure number 5.3, 5.4 and 5.5 it is clearly observe that as the Reynolds number and mass flow rate increases the Nusselt number also increases on the other hand as Reynold number increases the friction factor decreases and the Alternative elliptical shape roughness shows higher Nusselt number range varies from 25 to 88 with mass flow rate range 0.0786 to 0.475 and lowest range for friction factors varies from 0.0075 to 0.0035 . 

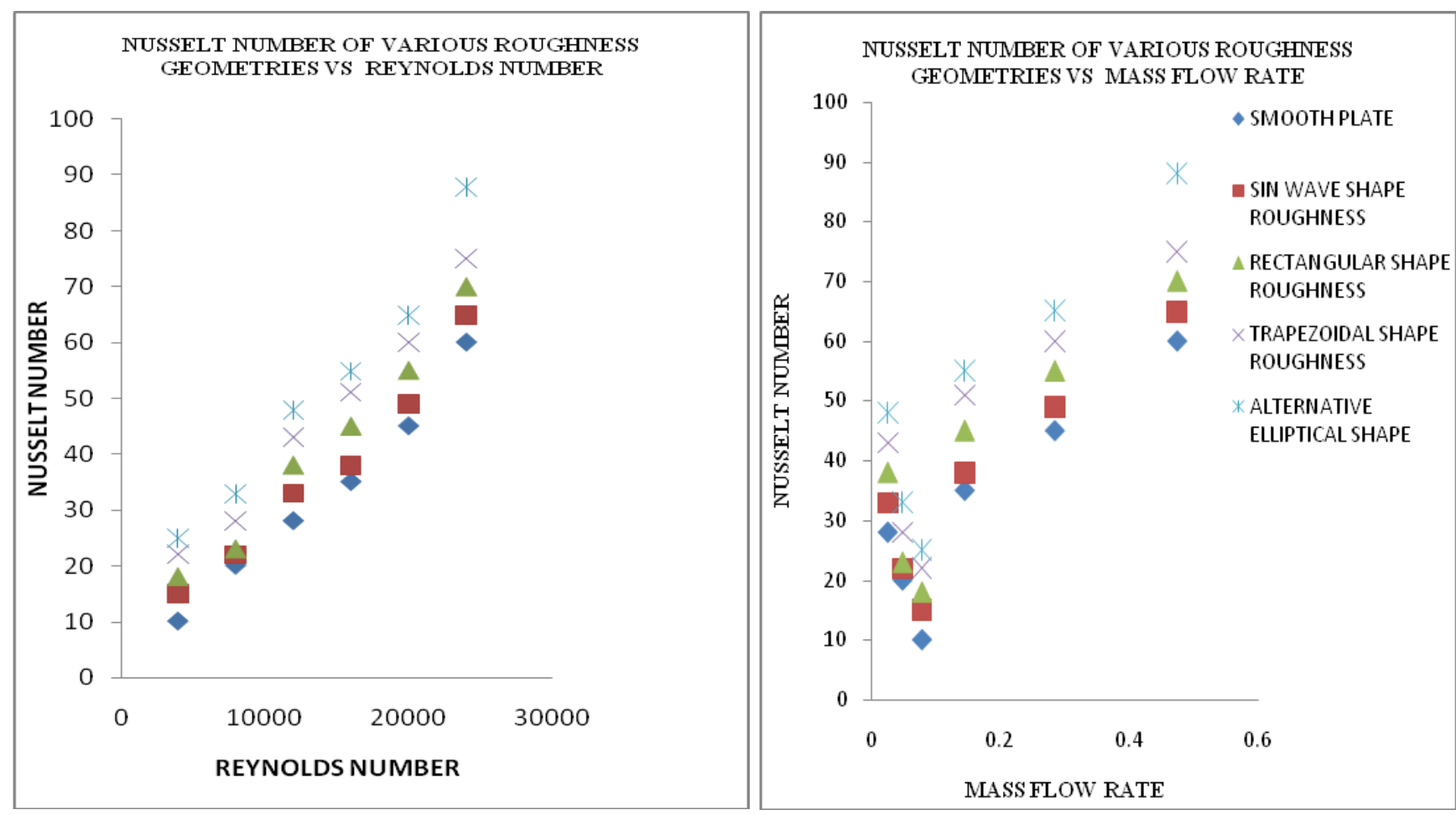

Fig 5.3: Graphical variation of experimental Nusselt Number of various roughness geometries Vs Reynolds Number.

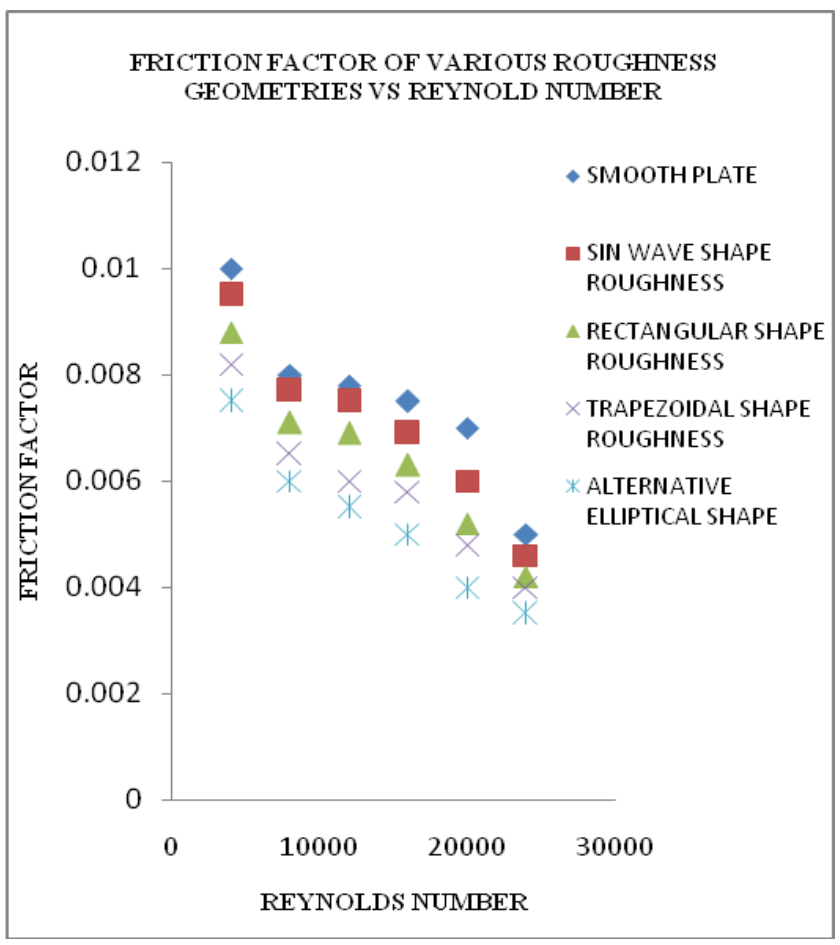

Fig 5.4: Graphical variation of experimental Friction Factor of various roughness geometries Vs Reynolds Number.
Fig 5.5: Graphical variation of experimental Nusselt Number of various roughness geometries Vs Mass Flow Rate.

These values of Nusselt number is greater than other geometries like smooth, sine wave, rectangular and trapezoidal roughness geometry shapes which varies from 10 to 60,15 to 65,18 to 70 and 22 to 75 . Similarly the above values of Alternative elliptical shape roughness geometry for Friction factor are very lowest than others which varies from 0.1 to $0.005,0.0095$ to $0.0046,0.0088$ to 0.0042 and 0.0082 to 0.0040 respectively. Thus, Alternative elliptical shape showed high heat transfer as compared to others.

\section{CONCLUSIONS AND FUTURE SCOPE}

In the present research study we experimentally investigating the sequel of spurious irregularity located over absorber salver of solar astir brazier passage of varying shapes like triangular, alternative elliptical shape pattern etc, with different mass flow rate on Nusselt Number and Friction Factor, but we present only the optimum result of heat transfer enhancement for promising shape among all other shapes for heat transfer, so that the future solar devices utilize maximum solar heat energy and promisingly able to transfer that same amount for energy to their destination. It is evidently shown from the above figures of graphical representation that as the mass flow rate is increases the values of Nusselt number will also increases but friction factor decreases on increasing values of mass flow rate because for higher value of mass flow rate we gained high pressure drop which were directly responsible for such results of friction factor. It also indicated that the high of mass flow rate were responsible for better heat transfer and thus, we also find the suitable optimum shape for heat transfer enhancement. The results also indicated the best optimum 


\section{Analysis on Heat Transmission and Fluid Flow Attributes in Solar Air Accumulator Passage with Diverse Faux Jaggedness Silhouettes on Absorber Panel}

heat transfer enhancement results for the alternative elliptical shape pattern shape artificial roughness as compared to all other artificial roughness shapes with range of $0.0786 \mathrm{~kg} / \mathrm{s}-0.475 \mathrm{~kg} / \mathrm{s}$ mass flow rate. The thermal efficiency for random parabolic pattern shape artificial roughness show best result as compared to all other artificial roughness shapes for optimum mass flow rate range. The theoretical percentage value of thermal efficiency achieved $78 \%$ through experimental data.

\section{REFERENCES}

1. Rahimi M, Shabanian S.R. and Alsairafi A.A., 2009. Experimental and CFD studies on heat transfer and friction factor characteristics of a tube equipped with modified twisted tape inserts. Chemical Engineering and Processing 48, 762-770.

2. Eiamsa-ard S, Wongcharee K, and Sripattanapipat S, 3-D, 2009. Numerical simulation of swirling flow and convective heat transfer in a circular tube induced by means of loose-fit twisted tapes. International Communications in Heat and Mass Transfer 36, 947-955.

3. Zhang Z, Ma D, Fang X, and Gao X,. 2008. Experimental and numerical heat transfer in a helically baffled heat exchanger combined with one three-dimensional finned tube. Chem. Eng. Process 47, 1738-1743.

4. Munoz-Esparza D, and Sanmiguel-Rojas E., 2011. Numerical simulations of the laminar flow in pipes with wire coil inserts. Computers \& Fluids 44, 169-177.

5. Kumar A., Chamoli S. and Kumar M., 2016. Experimental investigation on thermal performance and fluid flow characteristics in heat exchanger tube with solid hollow circular disk inserts. Applied Thermal Engineering 100, 227-236.

6. Bhuiya M.M.K., Sayem A.S.M., Islam M., Chowdhury M.S.U., Shahabuddin M., 2014. Performance assessment in a heat exchanger tube fitted with double counter twisted tape inserts. International Communications in Heat and Mass Transfer 50, 25-33.

7. Bhuiya M.M.K., Chowdhury M.S.U., Shahabuddin M., Saha M., Memone L.A., 2013. Thermal characteristics in a heat exchanger tube fitted with triple twisted tape inserts. International Communications in Heat and Mass Transfer 48, 124-132.

8. Bas H. and Ozceyhan V., 2012. Heat transfer enhancement in a tube with twisted tape inserts placed separately from the tube wall. Experimental Thermal and Fluid Science 41, 51-58.

9. Eiamsa-ard S. and Promvonge P., 2011. Influence of Double-sided Delta-wing Tape Insert with Alternate-axes on Flow and Heat Transfer Characteristics in a Heat Exchanger Tube. Chinese Journal of Chemical Engineering, 19(3), 410-423.

10. Eiamsa-ard S., Chinaruk T., Eiamsa-ard P. and Promvonge P., 2010. Thermal characteristics in a heat exchanger tube fitted with dual twisted tape elements in tandem. International Communications in Heat and Mass Transfer 37, 39-46.

11. Promvonge P., Eiamsa-ard S., 2007. Heat transfer and turbulent flow friction in a circular tube fitted with conical-nozzle turbulators. International Communications in Heat and Mass Transfer 34, 72-82.

12. Chang S. W., Yang T. L. Liou J. S., 2007. Heat transfer and pressure drop in tube with broken twisted tape insert. Experimental Thermal and Fluid Science 32,489-501.

13. L. Varshney and J. S. Saini, 1998. Heat transfer and friction factor correlations for rectangular solar air heater duct packed with wire mesh screen matrices. Solar energy 62, 255-262.

14. V.S. Hans, R.P. Saini, J.S. Saini, 2010. Heat transfer and friction factor correlations for a solar air heater duct roughened artificially with multiple v-ribs. Solar Energy 84, 898-911.

15. Brij Bhushan, Ranjit Singh, 2012. Thermal and thermohydraulic performance of roughened solar air heater having protruded absorber plate, Solar Energy 86, 3388-3396.

16. Prashant Dhiman, N.S. Thakur, Anoop Kumar, Satyender Singh,2011. An analytical model to predict the thermal performance of a novel parallel flow packed bed solar air heater. Applied Energy 88, 2157-2167.

17. A.A. El-Sebaii, S. Aboul-Enein, M.R.I. Ramadan, S.M. Shalaby, B.M. Moharram, 2011. Thermal performance investigation of double pass-finned plate solar air heater. Applied Energy 88, 727-1739.

18. Mohitkumar G. Gabhane, Amarsingh, Kanase-Patil, 2017. Experimental analysis of double flow solar air heater with multiple $\mathrm{C}$ shape roughness, Solar Energy 155, 1411-1416.
19. S.S. Krishnananth, K. Kalidasa Murugavel, 2013. Experimental study on double pass solar air heater with thermal energy storage. Journal of King Saud University - Engineering Sciences 25, 135-140.

20. Khushmeet Kumar, D.R. Prajapati, Sushant Samir, 2016. Heat Transfer and Friction Factor Correlations Development for Solar Air Heater Duct Artificially Roughened with 'S' Shape Ribs. Experimental Thermal and Fluid Science, http://dx.doi.org/10.1016/j.expthermflusci.2016.11.012

21. Fouad Menasria, Merouane Zedairia, Abdelhafid Moummi, 2017. Numerical study of thermohydraulic performance of solar air heater duct equipped with novel continuous rectangular baffles with high aspect ratio. Energy, 10.1016/j.energy.2017.05.002

22. L. Varshney, A.D. Gupta, 2017. Performance prediction for solar air heater having rectangular sectioned tapered rib roughness using CFD. Thermal Science and Engineering Progress, http://dx.doi.org/10.1016/j.tsep.2017.09.005

23. Smith Eiamsa-ard , Pongjet Promvonge(2009)."Thermal characteristics in round tube fitted with serrated twisted tape".Applied Thermal Engineering 30, 1673e1682

24. Abhishek Gautam, Lokesh Pandey, Satyendra Singh, 2017. Influence of perforated triple wing vortex generator on a turbulent flow through a circular tube, https://doi.org/10.1007/s00231-018-2296-4

25. N.T. Ravi Kumar, P. Bhramara, A. Kirubeil, L. Syam Sundar, Manoj K. Singh, Antonio C.M. Sousa(2018).Effect of twisted tape inserts on heat transfer, friction factor of $\mathrm{Fe} 3 \mathrm{O} 4$ nanofluids flow in a double pipe U-bend heat exchanger."International Communications in Heat and Mass Transfer 81, 155-163

26. Alok Kumar, Sunil Chamoli, Manoj Kumar, 2016. Experimental investigation on thermal performance and fluid flow characteristics in heat exchanger tube with solid hollow circular disk inserts. Applied Thermal Engineering 100, 227-236.

27. Seyfi Şevika, Mesut Abuşkab, 2019. Thermal performance of flexible air duct using a new absorber construction in a solar air collector. Applied Thermal Enginering 146, 123-134.

28. Alok Kumar, Sunil Chamoli, Manoj Kumar, Satyendra Singh, 2016. Experimental investigation on thermal performance and fluid flow characteristics in circular cylindrical tube with circular perforated ring inserts. Experimental Thermal and Fluid Science 79, 168-174.

\section{AUTHORS PROFILE}

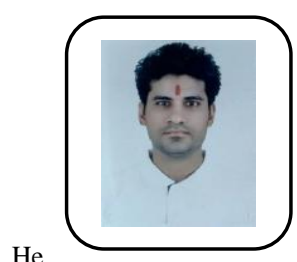

Shivasheesh Kaushik, is an Assistant Professor at Shivalik College of Engineering, Dehradun, India. He received his M.Tech. from B.T.K.I.T formerly known as K.E.C, Dwarahat in 2015 , India. Presently, he has research interest in Bio fuels pressure vessels and piping, plates and shells, composite materials and thermal analysis. is life Associate Member (Membership Number: AM1840951) in IEI organization and Certified Charted Engineer from IEI Organization. He has 5 to 8 publications in international and national journals and conferences. He has filed two patents.

Dr. Satyendra Singh, is an Associate

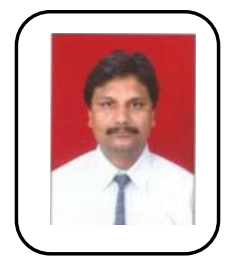
Professor at BTKIT, Dwarahat, India. He received his Ph.D. from IIT Delhi, India. Presently he is Head of Department of Mechanical Engineering and Dean (Academics). He has research interest in finite element analysis, dynamics of structures, pressure vessels and piping, plates and shells, composite structures and thermal analysis. He is life member of Indian society of Technical Education and Fellow of Institution of Engineers (India). He has more than hundred publications in international and national journals and conferences. He has filed two patents. 